\title{
The Return of Patriotism
}

\author{
Irina Vladimirovna Plyushch \\ Department of Theories and Techniques of Social Work \\ Siberian Federal University \\ Krasnoyarsk, Russia \\ reft@inbox.ru
}

\author{
Evgenia Nikolaevna Starovoitova \\ Department of Histor and Humanitarian Disciplines \\ Siberian State University of Science and Technology named \\ after Academician M.F. Reshetnev \\ Krasnoyarsk, Russia \\ jane_star78@mail.ru
}

\begin{abstract}
Annotation - The article presents an interpretation of the relationship between the value structure of mass Patriotic consciousness and social conditions of life. Living in an urban space changes the traditional Russian-speaking culture component of mass patriotic consciousness. On the basis of the analysis, the recommended directions for developing Patriotic education programs are determined.
\end{abstract}

Keywords - security, patriotism, mass patriotic consciousness, value, youth, state.

\section{THE RETURN OF PATRIOTISM}

The involvement of a large number of countries in the processes of globalization has given rise to the dream of the United humanity, the international government and even the disappearance of States. Many efforts have been made to realize this dream. Some attempts have survived in the form of individual international organizations, the European community and other associations. But unless humanity is ready to give up borders, it is not ready to unite. Perhaps the dream will remain only a dream. Currently, most countries are making efforts to develop patriotism among young people as a way to improve the security of the state.

In many countries, the willingness of young people to go to work and study in other countries is perceived as a real social problem. As in other matters, the needs of the government and the population may not coincide. The government undertakes to preserve the state. The population reacts as it feels. The state retains its integrity and independence as long as the population accepts the existence of the country and the core culture as a value. With the current aggravation of relations between countries and their associations in many states, the issues of preserving and spreading patriotism have been recognized as important for the state policy. Patriotism as an emotional and value-based devotion to one's country and culture is a point of support for governments. Those governments that hope to preserve their country not only in the texts of history textbooks but also in the real world. When young people identify themselves as belonging to the country, such a country will cherish as a personal value for these young people.

\section{PROBLEM STATEMENT}

\section{A. Patriotic consciousness as a systemic part of the national culture}

Patriotism in modern countries with a developed social policy has become an indispensable element of education of young people. Patriotic activity appears in the presence of patriotic consciousness as an image of a positive and emotionally significant country. It has been accepted as a historical fact that the concept of patriotism appeared in the XVII-XVIII century [1, 2, 3]. Patriotic education and patriotic consciousness are the concepts that have appeared not long ago and have not finished formation. Modern ideas are reduced to the fact that it is in the human mind that a unique image of the Homeland is formed, which consists of the basic socio-cultural values in the process of socialization $[4,5]$. The practical manifestation of patriotism in human actions can be considered a sign of patriotic consciousness. There are two main forms of patriotic consciousness - individual and mass [6]. Individual patriotic consciousness is a product of human socialization and is formed during one generation.

All educational efforts are aimed at forming the patriotic consciousness of the individual. But it is important to understand how the mass and individual patriotic consciousness interacts, how it affects the process of individual assimilation of patriotic attitudes. Mass patriotic consciousness is a little-studied phenomenon. It is not enough to think that mass patriotic consciousness is a mechanical set of individual patriotic ideas. The existing system of values moves to another, systemic, level of organization and influence. Any cultural system, which includes patriotic consciousness as a part, is characterized by a multiplicative effect. Mass patriotic consciousness can be designated as a cultural complex representing a part of the cultural system. This type of patriotic consciousness should be based on the values of a particular culture relevant to a long historical period. These are the values that determine the uniqueness of the national culture, its position in the world. Differences in national cultures suggest the existence of different basic values or part of them in the national patriotic components of culture.

Inevitably, the question arises about the possible differences in the understanding of positivity and value. Are positive values in the image of the country the same in different national cultures? What specific values make up the basis of national cultures in relation to the country? The answers to these and other questions determine the direction and stages for the formation of patriotic consciousness. The use of this knowledge in the construction of educational impact will provide a result corresponding to the consciously set goal. There are huge differences in values and hierarchies in most national cultures. Therefore, we can assume the existence of differences in national cultures and elements of patriotic consciousness. It is important to understand what 
elements of patriotism are obligatory for different cultures. Which ensure continuity. Which of them do not contradict cultural values and will not be rejected. As an example, we will analyze Russian patriotism as a value element of culture.

\section{B. Patriotic consciousness as a derivative of the element of identification}

The concept of patriotism in the Russian language appeared relatively recently $[7,8]$. But the phenomenon of patriotism as an element of consciousness and a behavioral value exists much longer. The prototype of patriotism in the history of mankind is devotion to the family, the feudal Lord, the representative of power (king) or any leader, an idea. Self-identification to a social group, recognition of identity with it was one of the elements of forming the personality and selfconsciousness. The same concerns the development of culture and civilization based on the marker we and they. Through the separation of himself from the "other" the individual was aware of himself and at the same time received socio-psychological support - "I am a part of the group", "I am not alone". At different times in different cultures we meet the identification of the individual with the inhabitants of the city, village, professional group (shop), religious community, political party. The need for identification is still an important part of socialization [9, $10]$.

More historically recent cultural formation is the identification of oneself through the country, the state. There is a possibility that for some modern cultures this stage of development is in a situation of formation. In other words, for some national cultures identification through the country did not arise in culture and is not implemented in individual socialization as a mandatory part of identification. We see that for the inhabitants of some States, the deterioration of the quality of life in their country is the reason for many people to leave for another country. The people of such countries are not making efforts to improve their lives in their country. According to preliminary data, in 2017, the European Community received just over 5 million new migrants who arrived for permanent residence [11]. There are many strong young men among migrants, but they did not try to change the situation at home. In their minds, perhaps, there is simply no value of patriotism.

In the foreground of public consciousness there are active fragments of modernity, the most unstable, mobile, problem. They are significant for a particular generation. The deep elements of mass consciousness, values must be stable for centuries or remain important for several generations. Such values should be fixed in the cultural layer. The purposeful transfer of any cultural element involves understanding its features. We will try to find the features of patriotism in the mass national consciousness on the example of the Russian culture.

\section{METHODS AND MATERIALS}

The study of mass Patriotic consciousness and the search for the values of national culture in relation to the country inevitably includes two levels of research. The first level is designed to find and identify possible sustainable values for the studied culture. These should be values that have remained relevant for at least centuries. Their significance for culture can also be confirmed by their inclusion in cultural works recognized as carriers of the essence of culture, reflecting its uniqueness. Thus, two indicators were taken into account-duration as an indicator of stability of acceptance in culture and recognition by the national community as an indicator of consistency with modern cultural values. It was assumed that the content analysis of such works will reveal:

- The presence / absence of repetitive emotionally significant elements of culture, which can be attributed to the manifestation of national Patriotic consciousness.

- Determination of the meaning of these elements, subject to their availability.

- Identification of the cultural elements found in the Patriotic context.

To find elements of mass national consciousness, early samples of Russian culture were studied using the method of content analysis. There is a small number of such samples, but all of them are recognized as carriers of the essence of Russian culture. These are such wellknown examples of culture as:

"A new story about the glorious Russian Kingdom and the great state of Moscow",

"The Tale of bygone years",

"The Word of the destruction of the Russian land",

"The word of Igor's regiment, from the speech of Peter the Great before the battle of Poltava".

The second level of the study provided information about the current state of mass national consciousness of the younger generation. Sociological methods (questionnaires, interviews) were used to identify the actual content of patriotism in the modern young generation. In preparation for the scientific and educational international forum "Man, family and society: history and prospects of development" in Krasnoyarsk (2015), there was conducted a sociological survey of students of three major universities, in particular, of the Siberian Federal University (Department of social work), Siberian aerospace University (Institute of space technologies), Pedagogical University. The respondents were second- and third-year students (more than 200 people), 97\% of them - residents of Krasnoyarsk region. The age of young people ranged from 19 to 21 years. The numbers included less men (6\%) than women $(54 \%)$. The type of vocational education received ranged from socially oriented to technical.

The proposed questionnaire was aimed at identifying:

- The presence /absence of emotionally significant attitude to the country.

- An emotional attitude - from negative to positive.

- The key values with which the country of residence at the emotional level is correlated for young people. 
Students represented an important part of the Russian youth. Of course, this is only one layer that does not fully reflect the totality of opinions and positions of various social groups of young people in the country. But it is the youth receiving higher education that will have the greatest impact on the development of the state. This part of the youth is more purposeful and socially active than other groups of the younger generation of the Russian population.

\section{RESULTS AND DISCUSSION:}

\section{A. Culturally relevant texts}

The study of historical sources of early Russian culture reveals a stable element. We see that the basis of Russian patriotism has remained united for centuries. It has been preserved since the birth of patriotism as a cultural element and awareness. To refer to Russian patriotism, you can still use the phrase from the text of the early XVII ${ }^{\text {th }}$ century - "good-willed to Russian Kingdom" [12]. In this sense, patriotism becomes an element of self-identification through the certain attitude to the country. It should be noted that Russian patriotism include at least two components that distinguish the Russian socio-cultural content of this concept. Almost all early Russian cultural texts represent the emotional significance of the country as a cultural space. This value of the country is referred to as something other than loyalty to a particular group or individual. At the same time, it is not just the space of direct residence of the family, tribe, nationality that is significant. The value is constituted by the space of culture distribution (Russian land). We should also note that this element was made emotionally significant long before the emergence of the Central government and statehood under a single administration. And it remains while a single state with monarchical rule is being formed. There is a conclusion about the early formation of mass patriotic consciousness and the preservation of its foundations for a long time.

In the early texts, there was always a reference to the Russian land in a broader sense than property, a space for life, a land for processing. Long before the emergence of concepts the Homeland, culture, civilization, ancient Russian texts used key descriptive phrases, such as "where did the Russian land appear" [13] (The tale of bygone years), "The word on the destruction of the Russian land" [14], "Woe befell the Russian land and the people" [15] (The word on Igor's regiment). As you can see, the use of the sustainable expression contextually shows the integrity of the perception of culture and territory, their certain inseparability.

Most texts of the last centuries use the concept of Homeland, e.g. in the texts of Peter I - "For the state, for his seed, for the Homeland" [16], in the documents of the XVIII-XIX ${ }^{\text {th }}$ centuries: "For faith, Tsar and Homeland" [17]. And in this case, the concept of Homeland was used to refer to a broader concept, not limited to any of the mentioned components. Homeland is not only a state or a place of life of its kind (a family), people of the same denomination (Christians or a nation). The Homeland is defined as a more important part, the space of culture in a particular territory. The concept of Homeland in the Russian culture has always meant a kind of real space.
It is possible that a kind of direct continuity remained between the concepts for a long time while the forms of patriotic consciousness were changing. And both the earlier forms and the later ones always attracted people, not connected with the state and not limited with faith. In the literary and historical documents of the Russian culture, there is always allocated the space as something common for the people using primarily Russian to communicate. So, there is an assumption about the first feature of the Russian patriotic consciousness before the concept of patriotism emerged. The ethno-confessional community of people in the Russian cultural context (at the level of mass consciousness) has always been associated with the territory in the modern geographical understanding of space. The Homeland is the Russian land surrounding a person's geographic space.

The second feature of mass patriotic consciousness is the role of natural components in perceiving the Motherland. In the Russian space, the basis is composed of natural components (rivers and ravines, fields and forests, natural phenomena, inseparable from the human life). It is important that these elements of space are often presented in an unchanged state, not transformed by people. In most Russian literary works, love for the Motherland and patriotism are expressed through the description of nature as a symbol and the embodiment of love for the Motherland. A. Pushkin, M. Lermontov, S. Esenin, A. FET are the recognized demonstrators of the Russian culture. In order to express love for the Motherland, each of them writes about nature. And most other writers and poets follow the same tradition. This pattern makes it possible to speak unambiguously about Russian patriotism as patriotism marked in the natural space. Patriotism in this embodiment is formed through the emotional perception of natural objects, natural phenomena, through the self-identification with the natural space. The preservation of the relationship between the emotional attitude to the Motherland and the natural content of this concept for a Millennium testifies to the key importance, universality of this element in Russian patriotism, Russian mass consciousness and Russian culture.

Thus, we can assume that the self-consciousness of the Russian person according to the language and culture (in modern terms - self-determination) regardless of origin ("earth and blood") has always been based on the elements of the natural environment and geographical space. That is why the forms of power and dynasty, ideology, type of state could change but people felt their unity with the space of the Motherland and the continuity of culture. The state is recognized as a value because it is located on the Russian land, that is, it acts as a secondary value element of mass consciousness.

\section{B. Patriotic consciousness of students of the XXI ${ }^{\text {t }}$ century}

Currently, patriotism is recognized as a complex socio-cultural formation. Patriotism includes a set of ideas and concepts, and at the same time the feelings and the behaviour of people. In the modern society, patriotism becomes an element of self-identification through the attitude to the country of birth, residence, culture. Such elements of self-identification are stable components of culture and include the most significant value bases for each culture. Modern civilization has 
significantly changed the living conditions of the population which leads to the transformation of the foundations of national cultures and, accordingly, selfidentification and the value system. Globalization of civilization creates new factors of influence. But different countries are involved in the processes of globalization to varying degrees. The effects of globalization are different depending on the impact on the daily life of the population. Currently, the globalization of the information space is the most important for the Russian population. Modern information space provides access to various models of norms and values, different from the traditional system of values of Russian culture. The second important factor of globalization is the spread of the urban lifestyle. The city is not just a place of local residence for people. The city is also the basis for a different social relationship and another organization of life.

Let us consider these changes on the example of the phenomenon of patriotism in the Russian culture. Traditionally, Russian patriotism was based on the great importance of emotional imprinting of natural components. This feature is reflected in a large number of literary works, poetry and prose. It is natural environment that was associated primarily with the Motherland. In the space of Russian culture, the basis is natural components (rivers and ravines, fields and forests, natural phenomena, inseparable from people's lives). In most Russian literary works, love for the Motherland and patriotism are expressed through the description of nature as a symbol, the embodiment of love for the Motherland. Pushkin, Lermontov and Yesenin, expressing love for the Motherland, write about nature.

However, modern society carries out everyday life in qualitatively different condition - in urban space. In technology-oriented countries, the majority of the population lives in urban conditions. In Russia, more than $70 \%$ of the society belongs to the urban population [18]. Urban space is becoming a habitat for the third of the Russian population. There is a number of issues related to the formation of patriotism. In particular they include:

- what will be the emotionally significant basis of patriotism in terms of urban space;

- if the continuity of values is going to be preserved;

- what will be the mechanism of formation of patriotism in the new conditions, etc.

Sociological surveys of modern youth show the change of value bases in the mass patriotic consciousness. More than $94 \%$ of young people demonstrate the presence of positively oriented mass patriotic consciousness. But the main value element is not the space of culture and natural elements. The main value, on which the attitude to the Motherland is based, is the value of the family and the communicative environment among young people. At present, young people have a predominance of ideas about the Motherland as a place of residence of the family. The results of the survey showed a clear predominance (more than $70 \%$ ) among the age group of $18-20$ years of perceiving the Motherland as the place of residence for the family, or even the environment for family communication and the immediate environment (friends).
Analysis of statements in the Internet space shows the presence of similar judgments in other territories of the country. The identity through the traditional values of national patriotic consciousness (natural elements) is found among the students who grew up in rural areas.

As you can see, the value system of youth is changing the foundations of patriotism. This attitude is widespread among young people and is very symptomatic. The emotional and value basis for patriotism as a family determines a number of completely different characteristics of both patriotism and the mechanism of its formation.

Identification of patriotism through the family or group communication is socially less stable, more dynamic and much more vulnerable to any external influences. The family as a social group can break up, change the place of residence, lose emotional ties. The environment of teenagers and young people is even more unstable and tends to change dramatically during the periods of identity formation. It is important that achieving a certain socio-cultural unity through the family does not provide emotional and value attitude to the country, society and culture. Here is an example of one of the most sharp and emotional statements in Internet communications. "I do not like my homeland (Homeland) for a long time and with conviction. And this does not prevent me from living in my native city, reading and thinking in my native language, loving my work and dreaming about the future. I love my family, my dead parents, my husband, my friends" [19]. So, for today's young people it is pretty common to feel where my family is, where my social environment is - there is good for me, there is my homeland. The sociopsychological space of patriotism is narrowed down to a communicative space with family or friends. The space that really exists on the material level disappears from the system of values. It should be noted that the concept and the phenomenon of nostalgia has practically disappeared as a socio-psychological difficulty to live far from home.

Thus, the consciousness of the Russian language and culture (in modern terms - self-determination) regardless of the origin ("earth and blood") consisted of the elements of the natural environment for a long time. In modern conditions, this relationship is eroding, losing its importance. Currently, the family and friends serve as a certain basis for forming patriotism. These elements have cultural value and can be the basis of emotional significance. But at the same time, they are more mobile and versatile. The family and a social circle can move to any country and therefore are a weaker foundation of patriotism.

\section{DifFICUltiES OF PATRIOTIC EDUCATION}

Patriotism as any phenomenon of culture is historical, that is, it arises and undergoes a number of changes together with the society and culture. As a result, in each specific period of time patriotism is a complex formation, including fragments of social consciousness of previous periods and new elements in the process of formation, reflecting current changes. That is why the process of interpreting this concept is so complicated and the attempts to put into practice the transfer of patriotism to the next generation as one of the fundamental values are 
even more difficult. Purposeful transfer assumes understanding of features of the Russian patriotism, existence of the mechanism of its formation, structures and techniques.

Patriotism as a way of thinking, emotional component of the value of the Motherland and ideology was formed on two grounds. The first included family education as a part of a lifestyle. At the same time, patriotism was formed in the process of shared experience with family members during emotionally coloured events, impressions, actions - shared work, shared rest or individual events. In Russia, the way of family life has always been associated with the natural environment, occurred within natural landscapes. Personality was formed and experienced the stages of emotional development in the natural environment, thereby creating an emotional connection between its inner world and the surrounding natural environment. This is confirmed by numerous references to natural phenomena, the details of the landscape in the literary works of Russian prose and poetry, the emotional passion of the works. Patriotism in this embodiment is largely formed through the emotional perception of natural objects, natural phenomena, through self-identification with the natural space.

In today's technologically developing country, the function of socialization of older children and adolescents is carried out within the education system, the sphere of social activity, using the media. The need for safety and control for large groups of children and adolescents is easier to implement in a confined space. The training system and the technical support of the training also need the predominant activity in the premises. The main emotions acquired be a modern child or teenager while growing up are associated with being in a group of peers and interacting with adults. At the same time, the space, in which a child or a teenager develop, and adults, who surround him or her, are not connected by deep emotional feelings. Space and adults remain strangers to the child. Own space and important emotional connections remain for him within the family.

At the same time, environmental conditions have changed significantly - as you know, more than $70 \%$ of Russian population live in cities. Urbanization processes have contributed to the separation from natural landscapes, the daily lifestyle of most modern people does not involve active interaction with natural landscapes. The majority of the Russian population lives far from natural conditions. Thus, the spontaneous development of patriotism is significantly limited as a result of changes in the conditions of socialization.

Of course, the cultural need formed over the centuries does not disappear without a trace in a short period. The need for interaction with natural elements manifests itself in the emergence of cultural traditions that mitigate such lifestyle changes. Cultural traditions are manifested in the organization within the separate families of individual preferences for leisure activities in the natural environment.

These types of leisure activities include "vacation in the village", fishing, hunting, active tourism, picking mushrooms and berries, suburban areas, summer camps for children, etc. During the second half of the 20th century in the Russian society there were many traditions in the urban environment as the implementation of culturally conditioned needs in direct interaction with the natural environment.

But the modern social conditions of Russian society are developing in such a way that leisure traditions of interaction with the natural environment are being destroyed. The natural change of demographic generations leads to the absence of ties with rural settlements in many families. The economic difficulties of recent decades have reduced the ability of the state to maintain a high level of social security and, at the same time, increased competitiveness in the labour market. These factors contributed to the tightening of working conditions - increased working time, reduced rest period (number of days off, the duration of leave, limited amount of the sick leave). The possibilities of the ablebodied population to leave and organize leisure activities in natural conditions are reduced. At the same time, the leisure industry in the city, in the immediate vicinity of the place of residence and work, is growing dramatically. The ability to provide recreation in natural conditions is lost for a large part of the Russian population and the need itself is also gradually lost. There is a replacement of the natural environment with the urbanized one, there disappears a spontaneous mechanism of forming patriotism as an emotional community with the territory embodied in natural elements and complexes. As a result, there is a social problem of identification of youth with the homeland. Patriotism loses its natural basis and is limited by the mechanism of family ties.

In fact, we can say that the traditional mechanism of forming patriotism is significantly weakened. If we are convinced that at the state level it is necessary to continue to use patriotism as a regulator of population behaviour, it is important to transfer this activity from the field of uncertainty and chance. Currently, the authors see two likely areas of activity. They can be described as traditional and innovative. Within the framework of the traditional direction, it will be necessary to identify the basic values of patriotic consciousness for the particular culture and to rely on these values in the development of the system of patriotism education. To implement the innovative direction, it will be necessary to analyze the features of the modern social environment and search for values that meet the realities of these living conditions of the population. Therefore, it is necessary to return to the basic values (in Russian culture, as mentioned above, these are natural elements and complexes) or create the new ones that meet the peculiarities of the modern living environment (urban conditions).

\section{ACKNOWLEDGMENT}

This research was initiated by the enthusiasm and curiosity of young people. First of all, it concerns the students of the Department of social work of the Siberian Federal University, who defended their point of view in discussions very emotionally and with conviction. They believe that the presence of patriotism among Russian youth is an important element of consciousness. And they also believe in the importance of patriotism in the modern world as one of the foundations of worldview.

Their conviction and emotionality were amazing for the authors of the article representing the older generation. This surprise was the impetus for action in 
comparing the views of students from different universities. The unity of the attitudes of the majority of students of different universities made the authors think. The undertaken efforts in understanding modern processes of development and essence of patriotism and patriotic consciousness allowed formulating the main provisions of this article.

It should be noted that discussing these provisions with colleagues in teaching has a great influence of teaching practice. The opportunity to get an external response is very much appreciated. Such reviews allow you to learn other points of view and to shape your idea more accurately.

In conclusion, we would like to mention the goodwill and professionalism of the representatives of the organizing Committee of the conference "123", whose careful support aided the publication of the article.

\section{REFERENCES}

[1] J. Macionis, "Sociology", 14 edition, Pearson Education, 2011, $707 \mathrm{p}$.

[2] D.E. Kendall, "Sociology in Our Times: The Essentials", 8 edition, Wadsworth Publishing, 2011, $624 \mathrm{p}$.

[3] A. Giddens, "Sociology", Fourth edition, Blackwell Publishers Limited, Oxford, 2001.

[4] R.J. Brum, "New Sotiet: Sociology for the 21ct Century", Harcourt brace \& Co, Canada, 1995.

[5] M. Haralambos, and M. Holborn, "Sociology: Themes and perspectives", 3rd Edition, Harper Collins, 1991.
[6] B.C. Turner, "The Cambridge Dictionary of Sociology", Cambridge University Press, 2006.

[7] A.S. Panarin, "Ortodoxs civilization", Institute of Russian civilization, Moskow, 2014.

[8] S.A. Magaril, "The meanings of patriotism: historical transformations", in Sociological research, No. 1, pp. 142-151, 2016.

[9] R. Hadeborn, "Sociology", 3 edution, Polity Press Blackwell Pullishers ltd, Oxford, 1997.

[10] G. Ritzer, "Modern sociological theory", McGraw-Hill Humanities, 2010, 832 p.

[11] "International Migration Outlook 2018", Berlin, OECD Center, 22. 06.2018, URL: https://bit.ly/2M8LOkJ.

[12] "New story about the glorious Russian Kingdom and the great state of Moscow", URL http://olegusenko1965.narod.ru/olderfiles/1/17_v_Novaya_povest o_preslavnom_Ro-17926.pdf.

[13] "The Tale of bygone years", URL: http://lib.ru/HISTORY/RUSSIA/povest.txt.

[14] "The Word of the destruction of the Russian land", URL: http://www.portal-slovo.ru/history/35616.php.

[15] "The word about Igor's regiment", URL: http://oldrussian.chat.ru/08slovo.htm.

[16] "From Peter the Great's speech before the battle of Poltava", URL: http://avtonomka.org/literatura/838-глава-3-наследникиморского-корпуса-петра-великого.html.

[17] F. Guide, "For faith, Tsar and Fatherland: to the history of the famous military motto", URL: http://www.pravoslavie.ru/61882.html.

[18] K. Larina, "Statement on Facebook", URL: https://www.facebook.com/xenialarina/posts/667282389980249?s tream_ref $=10$. 